\title{
Characteristics of gas evolution profiles during coal pyrolysis and its relation with the variation of functional groups
}

\author{
Lu Zhang $^{1}$ (I) $\cdot$ Shichao $\mathbf{Q i}^{1} \cdot$ Norihiro Takeda $^{1} \cdot$ Shinji Kudo $^{1,2} \cdot$ Junichiro Hayashi $^{1,2} \cdot$ Koyo Norinaga $^{1,2}$
}

Received: 15 March 2017/Revised: 3 May 2017/Accepted: 8 July 2017 / Published online: 26 July 2017

(C) The Author(s) 2017. This article is an open access publication

\begin{abstract}
Strict relation between the substituents or functional groups attached to the coal macromolecules and the generation of the volatile products, e.g., $\mathrm{CH}_{4}, \mathrm{H}_{2} \mathrm{O}, \mathrm{CO}, \mathrm{CO}_{2}$, etc., during the coal pyrolysis is an important but confusing subject. In this paper, quadrupole mass spectrometry, gas chromatography, and ${ }^{13} \mathrm{C}$ nuclear magnetic resonance are applied to real-time monitoring the formations of volatile products, off-line quantitative determination of the total products from the pyrolysis of a sub-bituminous coal (SC), and the changes of diverse substitents in the SC along with coke foamation, respectively. These measurements are also performed for the pyrolysis of a caking coal to contrast SC. The qualitative and quantitative data reveal that, during coal pyrolysis, the functional groups related with the formation of $\mathrm{CO}$, i.e., ether, carbonyl, and anhydride, can directly generate $\mathrm{CO}$ via bond breaking, or take a detour of the formation of other intermediates via condensation and recombination firstly. Moreover, the formations of $\mathrm{CO}_{2}$ and $\mathrm{CH}_{4}$ are related to the direct removal of -COO- and $-\mathrm{CH}_{3}$, respectively.
\end{abstract}

Keywords Light gas evolution $\cdot$ Carbonization $\cdot \mathrm{QMS} \cdot \mathrm{GC} \cdot{ }^{13} \mathrm{C}$ NMR

\section{Introduction}

It is generally recognized that the heterogeneous structure of coal is formed by a complex three-dimensional macromolecular network cross-linked by short aliphatic and etheric bridges (Liu et al. 2014a, b). A variety of

Electronic supplementary material The online version of this article (doi:10.1007/s40789-017-0175-0) contains supplementary material, which is available to authorized users.

Lu Zhang

sdlszhanglu@163.com

1 Department of Applied Science for Electronics and Materials, Kyushu University, 6-1, Kasuga Koen, Kasuga, Fukuoka 816-8580, Japan

2 Institute for Materials Chemistry and Engineering, Kyushu University, 6-1, Kasuga Koen, Kasuga, Fukuoka 816-8580, Japan substituents, such as hydroxyl, ether, ester, carboxyl, and alkyl groups are attached to the discrete/condensed aromatic rings in coal to form the main structure of coal macromolecules (Poutsma 1990; Ndaji et al. 1997). Pyrolysis is a most generally used technology for downstream processing and clean utilizations of coal (Shabbar and Janajreh 2013). With the thermal decomposition of coal macromolecules, the substituents on the aromatic rings, including side substituents and bridged ones, are gradually deprived by the release of micromolecules, e.g., $\mathrm{H}_{2}, \mathrm{CH}_{4}, \mathrm{H}_{2} \mathrm{O}, \mathrm{CO}, \mathrm{CO}_{2}$, etc. (Arenillas et al. 1999). The relationships between substituents on aromatic rings and the volatile products have been extensively studied, but only qualitatively and superficially (Attar and Hendrickson 1980; Solomon et al. 1988; Ibarra et al. 1991; Solomon et al. 1993; Liu et al. 2012). For example, there were report indicating that methyl groups can be deprived and then capped by a hydrogen-free radical to form a methane at high temperature, while other reports concluded that at moderate temperatures the methane formation occurred as 
well even at moderate temperature, caused by cross-linking reactions. Therefore, mechanisms of the formation of volatile products in coal pyrolysis still remains inconsistent and elusive, even though new reaction models for coal pyrolysis have been proposed in recent years. (Solomon et al. 1988; Grant and Pugmire 1989; Fletcher and Kerstein 1990, 1992; Solomon et al. 1990a, b, c; Niksa 1991a, b, c, 1995; Solomon 1994; Tian et al. 2001).

To study the strict relations between the deprivations of substituents on aromatic rings in coal and the formation of volatile products in coal pyrolysis, the volatile products were always qualitatively or quantitatively analyzed by employing a variety of techniques, such as quadrupole mass spectrometry (QMS), Fourier transform infrared spectroscopy (FTIR), and gas chromatography (GC) (Dollimore et al. 1984; Solomom et al. 1990a, b, c). Many studies have successfully employed QMS and FTIR for real-time detecting the pyrolysis behavior of coal and its gaseous compounds evolution due to the rapid response and sensitivities of QMS and FTIR (Duan 2007; Duan et al. 2009; Wang et al. 2013a, b; Jia et al. 2013; Wu et al. 2014). FTIR is, however, not as sensitive as QMS for those micromolecules in the volatile products. Moreover, QMS and FTIR are always employed for qualitative analysis rather than quantitative one (Le et al. 2015). Compared with QMS and FTIR, GC operation is more accurate and reliable for quantitative analysis, but it has always to be off-line performed for compromising its defect of batch sampling. In addition, nuclear magnetic resonance (NMR) spectroscopy can provide powerful structure information on the different kinds of organic carbons, hydrogens, and oxygen-containing groups in coal, and additionally has good quantitative properties. The solid-state ${ }^{13} \mathrm{C}$ NMR spectroscopy has been widely applied to directly characterize the carbon structural features and functional groups in fossil fuel in the past several decades (Axelson 1985; Davidson 1986; Miknis 1996; Genetti et al. 1999; Perry et al. 2000; Sun et al. 2003; Wang et al. 2013a, b).

In this study, real-time measurements by QMS combined with off-line analysis by GC were performed qualitatively and quantitatively to analyze the evolution rate of each gas along with the pyrolysis of caking coal and subbituminous coal. ${ }^{13} \mathrm{C}$ NMR was performed to identify the structural information and the variety of organic carbons in raw coals and the corresponding staged char residues from the coal pyrolysis (Solum et al. 1989). Based on a famous coal model FG/DVC created by Solomon et al. (1992), we analyzed these data or information gotten from QMS, GC, and ${ }^{13} \mathrm{C}$ NMR systematically, and then presented the relationships between the substituents on aromatic rings in coal and the evolution products, as well as the potential mechanisms of gas formation during coal pyrolysis.

\section{Experimental}

\subsection{Samples}

Caking coal (North Goonyella, NG) and sub-bituminous coal (Adaro, AD) were used in this study. The proximate and ultimate analyses are listed in Table 1. The coal samples were pulverized to less than $75 \mu \mathrm{m}$ and dried under vacuum for $24 \mathrm{~h}$.

\subsection{Coal pyrolysis and analysis to the gas products}

Coal powders of $2.0 \mathrm{~g}$ were used in each experiment. As shown in Fig. 1, loose-packed coal powders were heated up to $900{ }^{\circ} \mathrm{C}$ with a heating rate of $5^{\circ} \mathrm{C} / \mathrm{min}$ in a horizontal quartz tube reactor, with using argon as carrier gas with a constant flow rate of $200 \mathrm{~mL} / \mathrm{min}$ (STP). Filtrated by quartz wool at the tail end of the quartz tube reactor, the volatile products from coal pyrolysis were detected by only one of two separated modes, QMS or GC.

QMS (M-QA100TS, ANELVA Corp.) was used for real-time monitoring. The volatile products were introduced into the QMS through a capillary, which was convolved by tape heater of $200{ }^{\circ} \mathrm{C}$ to avoid condensation of coal tar therein. A diaphragm pump was used to help transporting the gas into the QMS by reducing the tube pressure to 25 mbar. The delay time of QMS detection was thus decreased within $5 \mathrm{~s}$. The vacuum degree of QMS was kept at $1 \times 10^{-5}$ Pa before measurement, and at $1 \times 10^{-3}$ $\mathrm{Pa}$ during measurement. Other details of QMS operation were set as follows: ionizing voltage, $24 \mathrm{~V}$; emission current, $1.0 \mathrm{~mA}$; mass number range, $1-80 \mathrm{~m} / \mathrm{z}$; scan speed,

Table 1 Properties of coal NG and AD

\begin{tabular}{|c|c|c|c|c|c|c|c|c|}
\hline \multirow[t]{2}{*}{ Coal } & \multicolumn{3}{|c|}{ Proximate analysis } & \multicolumn{5}{|c|}{ Ultimate analysis } \\
\hline & $\begin{array}{l}\text { Moisture } \\
\text { wt } \%^{\text {b }}\end{array}$ & $\begin{array}{l}\text { Ash } \\
\text { d-wt } \%^{c}\end{array}$ & $\begin{array}{l}\text { Volatile } \\
\text { d-wt } \%\end{array}$ & $\begin{array}{l}\mathrm{C} \\
\mathrm{d}-\mathrm{wt} \%\end{array}$ & $\begin{array}{l}\mathrm{H} \\
\mathrm{d}-\mathrm{wt} \%\end{array}$ & $\begin{array}{l}\mathrm{N} \\
\mathrm{d}-\mathrm{wt} \%\end{array}$ & $\begin{array}{l}\mathrm{T}-\mathrm{S}^{\mathrm{a}} \\
\mathrm{d}-\mathrm{wt} \%\end{array}$ & $\begin{array}{l}\text { Ash-S } \\
\text { ash-wt\% }\end{array}$ \\
\hline NG & 2.2 & 9.1 & 23.1 & 81.2 & 4.57 & 1.79 & 0.51 & 0.11 \\
\hline AD & 4.9 & 1.2 & 48.6 & 72.8 & 5.06 & 0.90 & 0.13 & 3.79 \\
\hline
\end{tabular}

${ }^{\mathrm{a}} T-S$ Total sulfur; ${ }^{\mathrm{b}} w t \%$ weight percentage, ${ }^{\mathrm{c}} \mathrm{d}$ - dry basis 


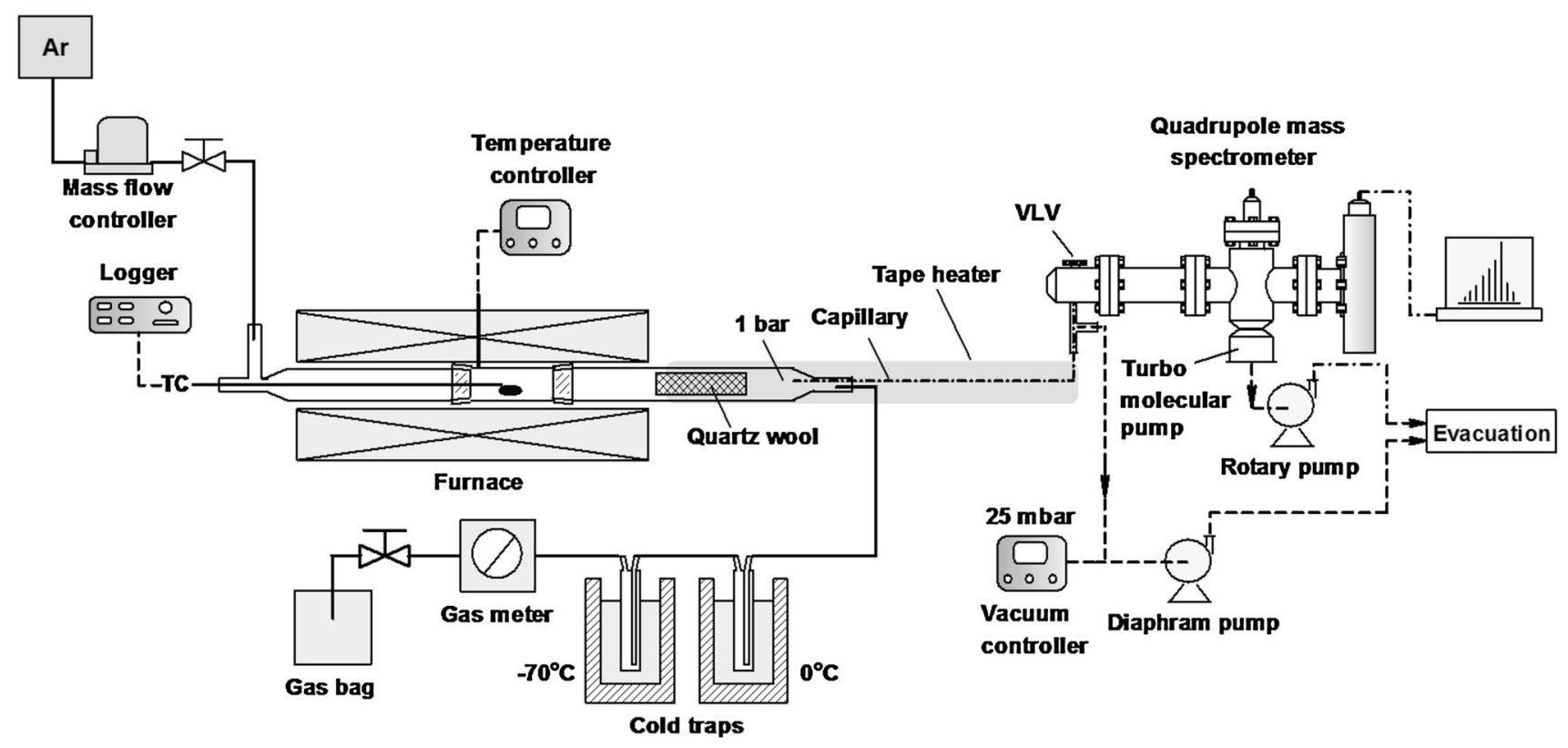

Fig. 1 Apparatus of horizontal tube reactor with quadrupole mass spectrometry

$100 \mathrm{~ms} / \mathrm{amu}$. Mass numbers of 2, 15, 18, 28, and 44 were selected to characterize the presences of $\mathrm{H}_{2}, \mathrm{CH}_{4}, \mathrm{H}_{2} \mathrm{O}$, $\mathrm{CO}$, and $\mathrm{CO}_{2}$, respectively. Real-time evolution curves of these five gases during coal pyrolysis were thus obtained.

GC-TCD/FID (Himadzu, GC-8A and GC-14B) was used for off-line detection. Sufficiently cooled in two cold traps $\left(0\right.$ and $\left.-70^{\circ} \mathrm{C}\right)$, the non-condensable volatiles were collected into a gas bag, and then analyzed by GC-TCD/ FID. $\mathrm{H}_{2} \mathrm{O}$ in coal tar, which had been retained by the quartz wool in tube reactor and the cold traps, was analyzed by Karl Fischer Moisture analyzer (MKC-210, KYOTO ELECTRONICS). Distribution of products from coal pyrolysis is shown in Table S1 (in Supplementary Information). The data that were obtained from off-line GC assisted the quantitative analysis of the evolution curves of gas products that were obtained from real-time QMS. Therefore, the function curves of gases production during coal pyrolysis with variables of temperatures were finally obtained by employing differential method.

Coal powders were further briquetted at ambient temperature and with mechanical pressure of $128 \mathrm{MPa}$ for $8 \mathrm{~min}$ (Mori et al. 2011). Each briquette (1.0 g) was heated up to different target temperatures at the same heating rate of $5{ }^{\circ} \mathrm{C} / \mathrm{min}$ with a $\mathrm{N}_{2}$ flowrate of $200 \mathrm{~mL} / \mathrm{min}$ (STP) in a vertical quartz tube reactor for heat treatment coals, as shown in Fig. 2. Once reaching the target temperatures, the char briquettes were instantaneously cooled down by falling into the bottom of the reactor immersed in liquid $\mathrm{N}_{2}$. Yields of heat treatment coals at different temperatures are shown in Fig. S1 (in Supplementary Information). Thermo-

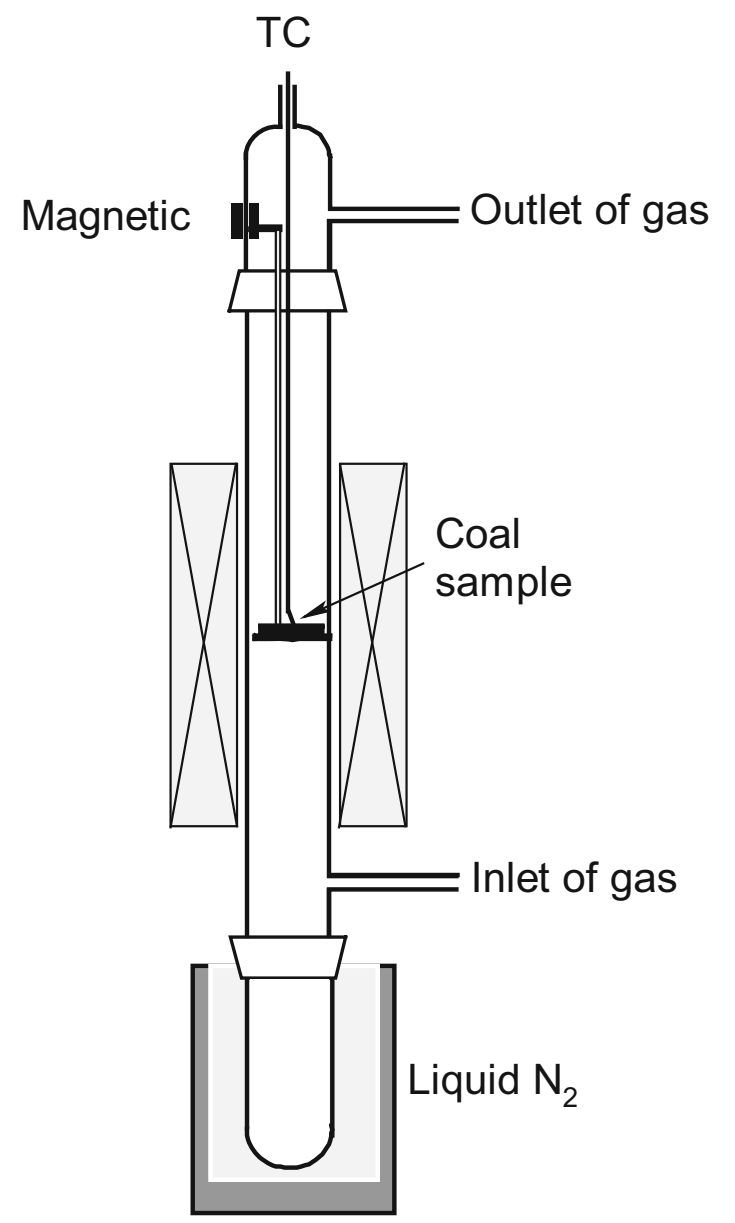

Fig. 2 Apparatus of vertical tube reactor for heat treatment coals 
gravimetric (TG) curves of the two coal samples were presented in that figure as well. Note that the TG curves are well consistent with those dots of yields, indicating the accuracy of our experiments. Residual heat treatment coals were then pulverized to powders for the characterizations by solid-state ${ }^{13} \mathrm{C}$ NMR spectroscopy. The NMR spectra were recorded with the DEPTH2 technique at $100.53 \mathrm{MHz}$ in a JEOL ECA 400 spectrometer. The repetition time was $20 \mathrm{~s}$. Magic angle spinning was performed at $15 \mathrm{kHz}$ in the commercial probe (JEOL 4 mm CPMAS). The ${ }^{13} \mathrm{C}$ NMR data were then analyzed by a variation of the method described by Solum et al. (1989).

\section{Results and discussion}

In our study, all the evolution curves of gases formation were deconvolved by several independent Gaussian-style functions, varying their parameters such as the locations, line widths, and intensities, to get the highest correlation coefficients. All the correlation coefficients of deconvolution results were higher than $99 \% .{ }^{13} \mathrm{C}$ NMR spectra were deconvolved based on the chemical shifts in previous reports (Solum et al. 1989; Kidena et al. 1999), analyzing the organic carbon varieties in the molecules of coal samples. With the help of elemental analysis of raw coal (Table 1), the organic carbons can be quantitatively classified into 8 varieties, i.e., methyl $\left(-\mathrm{CH}_{3}\right)$, methylene $\left(-\mathrm{CH}_{2}\right)$, aliphatic carbon with oxygen substituents $(\mathrm{Al}-\mathrm{O})$, protonated aromatic carbon $(\mathrm{Ar}-\mathrm{H})$, aromatic carbon with alkyl groups $(\mathrm{Ar}-\mathrm{C})$, bridgehead carbon, aromatic carbon with oxygen substituents (Ar-O), and carbonyl carbon $\left(\mathrm{O}=\mathrm{C}-\mathrm{O}, \mathrm{C}=\mathrm{O}\right.$ ) (see Tables 2 and 3). $\mathrm{CH}_{4}, \mathrm{CO}_{2}, \mathrm{CO}, \mathrm{H}_{2} \mathrm{O}$, and $\mathrm{H}_{2}$ are the main gas products from coal pyrolysis, and these gases are relative with specific functional groups of coal (Solomon et al. 1988, 1990a, b, c; Figueiredo et al. 1999; Kazuhiro et al. 2002), therefore, it is evident to quantitatively associate the gas outputs with the quantities of the functional groups.

\subsection{Mechanism of CO formation}

Figure 3 shows the yields of $\mathrm{CO}$ with elevated temperatures of coal pyrolysis, and the variations of the related $\mathrm{Al}-$ $\mathrm{O}$ and $\mathrm{Ar}-\mathrm{O}$. With the temperature elevated, $\mathrm{CO}$ formation is continuously increased, while the quantities of the two kinds of functional group $\mathrm{Al}-\mathrm{O}$ and $\mathrm{Ar}-\mathrm{O}$ are not linearly changed.

(1) Ar-O increases while $\mathrm{Al}-\mathrm{O}$ slightly decreased before $400{ }^{\circ} \mathrm{C}$. It was because the side carbon chains in coal transformed into aliphatic carbon rings, and ether bonds were dissociated at the relative low temperature range. To be specific, coking process at low temperatures during coal pyrolysis resulted in the ring formation of side carbon chains. When a side carbon chains contained a primary hydroxyl group originally, the ring formation would cause the formation of $\mathrm{Ar}-\mathrm{O}$ bonds (Reaction 1). Ether bonds

Table 2 Carbon distribution of coal AD, mmol/g-d

\begin{tabular}{lllllllll}
\hline Heat treatment temperature $\left({ }^{\circ} \mathrm{C}\right)$ & $\mathrm{CH}_{3}$ & $\mathrm{CH}_{2}$ & $\mathrm{Al}-\mathrm{O}$ & Bridgehead & $\mathrm{Ar}-\mathrm{H}$ & $\mathrm{Ar}-\mathrm{C}$ & $\mathrm{Ar}-\mathrm{O}$ & $\mathrm{COOC}=\mathrm{O}$ \\
\hline Raw coal & 5.1 & 11.7 & 2.1 & 16.0 & 8.2 & 6.4 & 7.0 & 1.8 \\
400 & 4.4 & 7.6 & 1.6 & 14.6 & 8.5 & 7.0 & 7.9 & 1.2 \\
450 & 3.5 & 5.2 & 1.8 & 13.4 & 8.4 & 6.6 & 6.0 & 1.0 \\
500 & 2.3 & 1.9 & 0.8 & 13.0 & 13.2 & 6.1 & 6.5 & 1.1 \\
600 & 0.9 & 1.1 & 0.5 & 11.8 & 17.1 & 5.6 & 4.1 & 1.1 \\
700 & 0.1 & 0.1 & 0.7 & 8.4 & 21.8 & 5.9 & 2.8 & 0.6 \\
\hline
\end{tabular}

$d$ dry basis

Table 3 Carbon distribution of coal NG, mmol/g-d

\begin{tabular}{llllllllcr}
\hline Heat treatment temperature $\left({ }^{\circ} \mathrm{C}\right)$ & $\mathrm{CH}_{3}$ & $\mathrm{CH}_{2}$ & $\mathrm{Al}-\mathrm{O}$ & Bridgehead & $\mathrm{Ar}-\mathrm{H}$ & $\mathrm{Ar}-\mathrm{C}$ & $\mathrm{Ar}-\mathrm{O}$ & $\mathrm{COOC}=\mathrm{O}$ \\
\hline Raw coal & 7.1 & 7.4 & 2.2 & 19.7 & 17.9 & 10.1 & 2.3 & 0.6 \\
400 & 6.7 & 7.5 & 2.4 & 20.8 & 17.4 & 8.8 & 1.8 & 0.5 \\
450 & 5.1 & 6.7 & 2.0 & 19.5 & 17.9 & 9.8 & 2.8 & 0.2 \\
500 & 4.8 & 3.8 & 2.1 & 18.5 & 26.0 & 4.4 & 2.0 & 0.2 \\
600 & 1.5 & 1.4 & 2.2 & 16.2 & 28.2 & 5.8 & 1.7 & 0.4 \\
700 & 0.6 & 0.6 & 0.8 & 13.5 & 29.9 & 8.0 & 1.6 & 0.5 \\
\hline
\end{tabular}

$d$ dry basis 


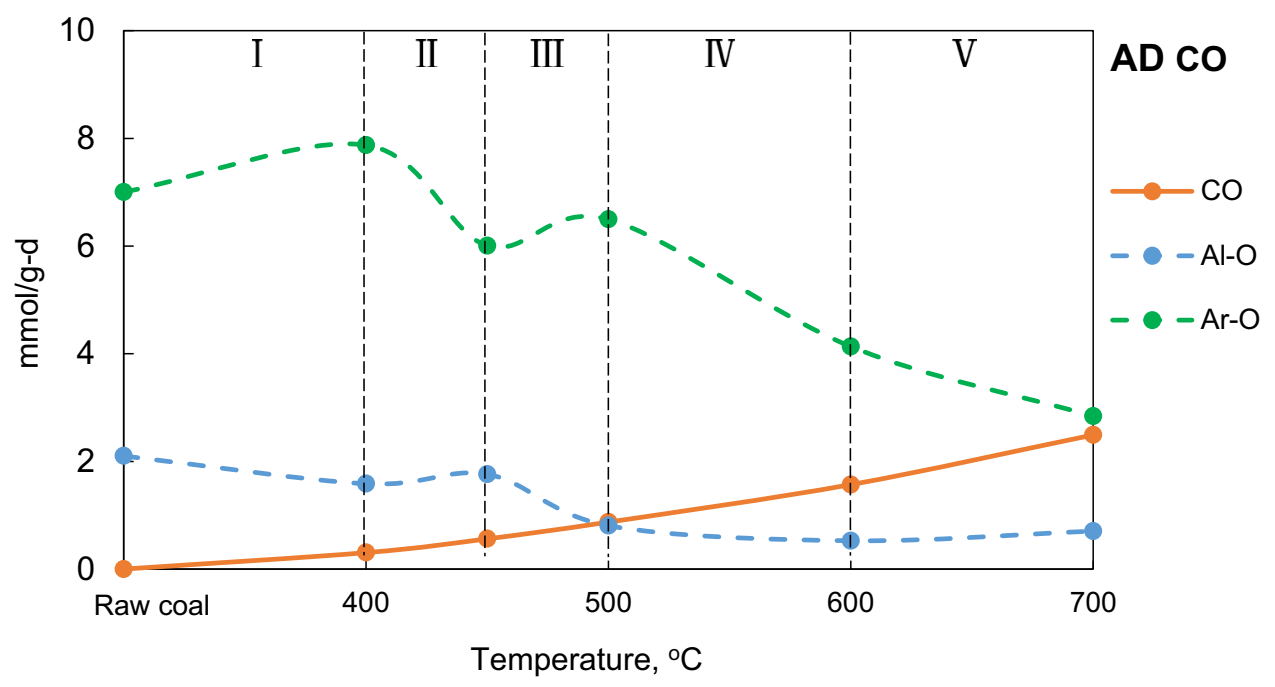

Fig. 3 Integration of $\mathrm{CO}$ as a function of temperature and the trends of its relevant functional groups of $\mathrm{Al}-\mathrm{O}$ and $\mathrm{Ar}-\mathrm{O}$ of coal $\mathrm{AD}$

were also easy to be dissociated during coal pyrolysis at low temperature, producing $\mathrm{CO}$ gas or carbonyl group, which should be the reason for the quantity of $\mathrm{Al}-\mathrm{O}$ decreasing (Reaction 2). In the reactions, (coal)Ar- denotes the layer structure of aromatic rings in coal, while $\mathrm{R}$ - represents the substituents such as alkyl groups or aromatic rings.
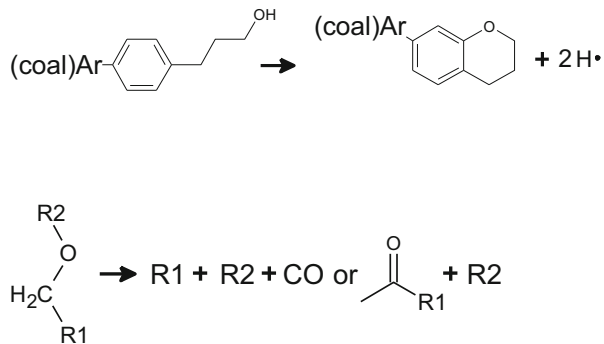

(2) At the temperature range from 400 to $450{ }^{\circ} \mathrm{C}$, the quantity of Ar-O decreased greatly while that of Al$\mathrm{O}$ elevated slightly. In this stage, the formation of $\mathrm{CO}$ was not only related with Reaction 2, but also with Reaction 3. As shown in Reaction 3, the carbonyl group will be generated from the cleavage of $\mathrm{Ar}-\mathrm{O}$ bond of $\mathrm{Ar}-\mathrm{O}-\mathrm{R}$, only if - $\mathrm{R}$ denotes longchain alkyl groups. $\mathrm{CO}$ is also possible to be formed only if - $\mathrm{R}$ represents $-\mathrm{CH}_{3}$. In addition, $\mathrm{Al}-\mathrm{O}$ slightly increasing at the temperature range was probably attributed to the transferred ether groups from aromatic rings to side chains (see Reaction 4).

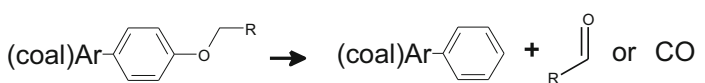

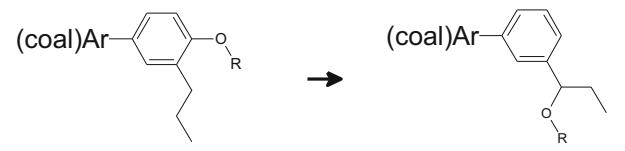

(3) At the temperature range from 400 to $450{ }^{\circ} \mathrm{C}, \mathrm{Ar}-\mathrm{O}$ increases while $\mathrm{Al}-\mathrm{O}$ deceases. In this stage, the formation of $\mathrm{CO}$ was still attributed to Reactions 2 and 3. In addition, other reactions such as the condensation between O-containing heterocyclic compounds and aromatic rings, and aromatization of cycloalkanes should occur in this stage. Both of these two reactions can increase the quantity of Ar$\mathrm{O}$ (Reactions 5 and 6). Moreover, according to these two reactions, the quantity of bridgehead $\mathrm{C}$ atoms should be increased simultaneously, which is also verified by the AD profile in Fig. 4.
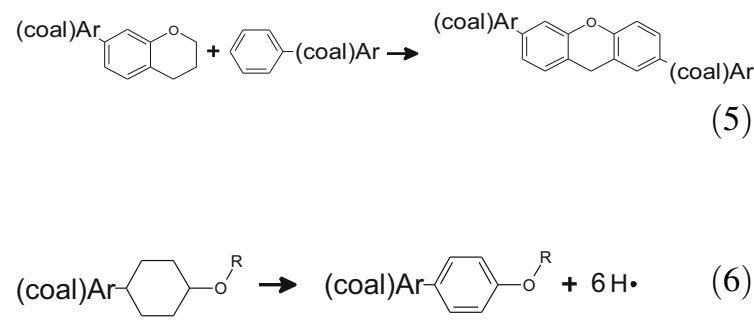

(4) At the temperature range from 500 to $600{ }^{\circ} \mathrm{C}$, the quantity of $\mathrm{Ar}-\mathrm{O}$ begins decreasing significantly, while that of $\mathrm{Al}-\mathrm{O}$ is continuously decreasing. In this stage, there was still $\mathrm{CO}$ gas generated through Reactions 2 and 3. Meanwhile, with deprivation of $\mathrm{O}$ atoms to form oxygen free radicals and to produce 


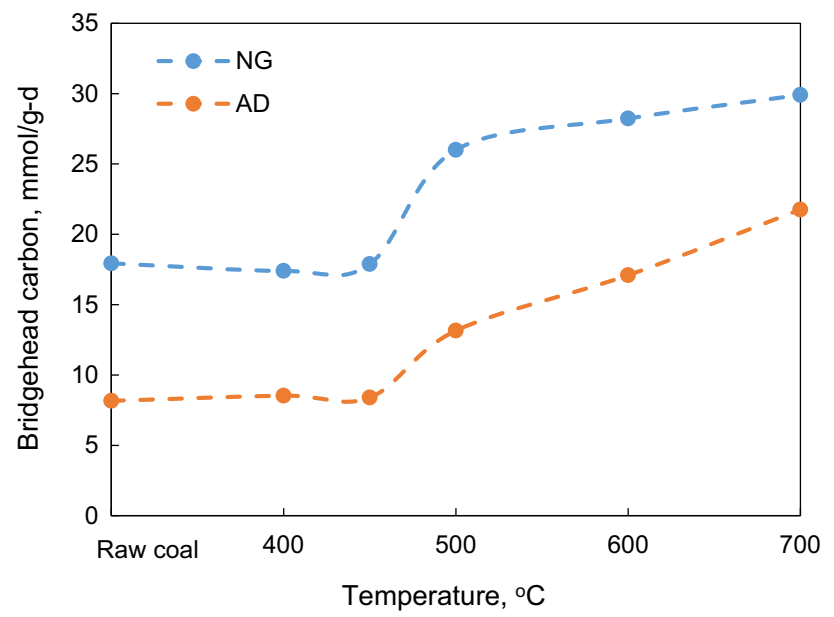

Fig. 4 Trends of bridgehead carbons as a function of temperature of coal NG and AD

$\mathrm{CO}$ eventually, the O-containing aromatic rings started to condense, forming bigger condensed arenes. As a result, the quantity of $\mathrm{Ar}-\mathrm{O}$ decreased largely.

(5) Above $600{ }^{\circ} \mathrm{C}, \mathrm{Ar}-\mathrm{O}$ decreases continuously due to the presence of Reaction 7, while Al-O increased slightly since a few oxygen free radicals reacted with the side substituents of aromatic rings (Reaction 8).

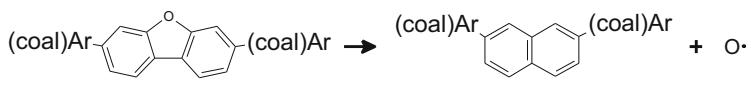

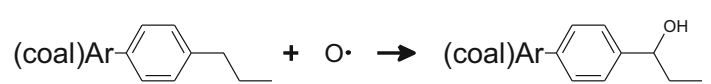

As shown in Tables 2 and 3 and Fig. 5, compared with $\mathrm{AD}, \mathrm{NG}$ contains similar quantity of $\mathrm{Al}-\mathrm{O}$ but less $\mathrm{Ar}-\mathrm{O}$, while the $\mathrm{CO}$ formation of $\mathrm{NG}$ is less than that of $\mathrm{AD}$. This further verifies that the formation of $\mathrm{CO}$ is closely relative with $\mathrm{Ar}-\mathrm{O}$. It is interesting that the variation profiles of $\mathrm{Ar}-$ $\mathrm{O}$ and $\mathrm{Al}-\mathrm{O}$ of $\mathrm{NG}$ at the temperature range from ambient to $600{ }^{\circ} \mathrm{C}$ are similar with those of $\mathrm{AD}$ at the temperature range from 400 to $700{ }^{\circ} \mathrm{C}$. This phenomenon implies that the molecular structures of NG might be similar with those of $\mathrm{AD}$ after treatment of pyrolysis at low temperatures. From ambient temperature to $600{ }^{\circ} \mathrm{C}$, the $\mathrm{Ar}-\mathrm{O}$ in $\mathrm{NG}$ should react successively as Reactions from 3 to 7 , while $\mathrm{Al}-\mathrm{O}$ should react as Reactions 2, 6, and 8. When the temperature was elevated above $600{ }^{\circ} \mathrm{C}$, the quantity of Ar-O remained unchanged, while $\mathrm{Al}-\mathrm{O}$ decreased greatly to form $\mathrm{CO}$ gas. This was mainly because the further pyrolysis of side substituents on aromatic rings occurred as Reaction 8.

According to the above-mentioned analysis about the $\mathrm{CO}$ formation and the variations of related functional groups, we deconvolved the $\mathrm{CO}$ formation rate profiles of NG and $\mathrm{AD}$, and further identified each independent reaction we proposed. According to previous reports, the $\mathrm{CO}$ formation of coal pyrolysis was closely related with three to five potential reactions (Seebauer et al. 1997;

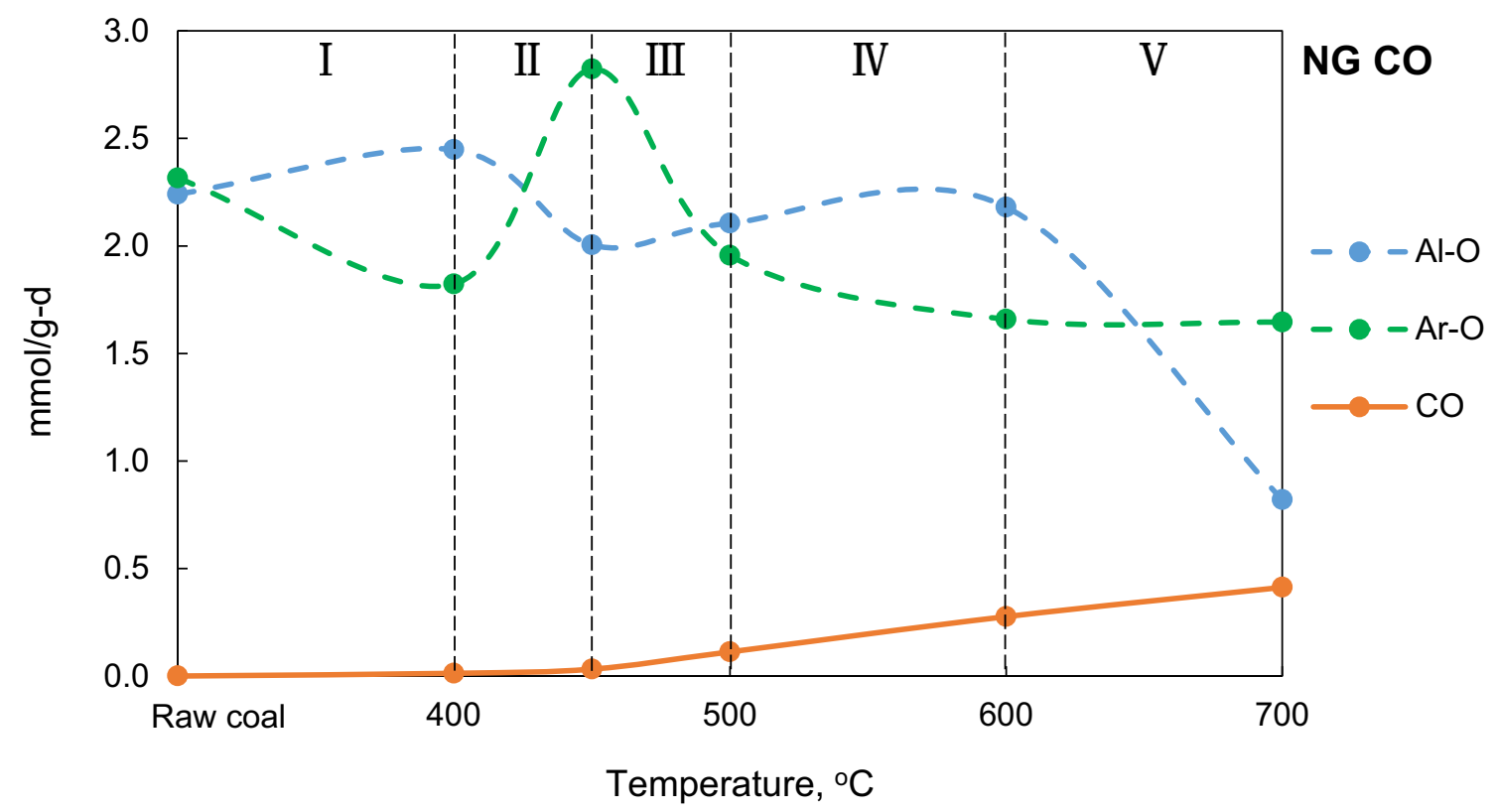

Fig. 5 Integration of $\mathrm{CO}$ as a function of temperature and the trends of its relevant functional groups of $\mathrm{Al}-\mathrm{O}$ and $\mathrm{Ar}-\mathrm{O}$ of coal $\mathrm{NG}$ 


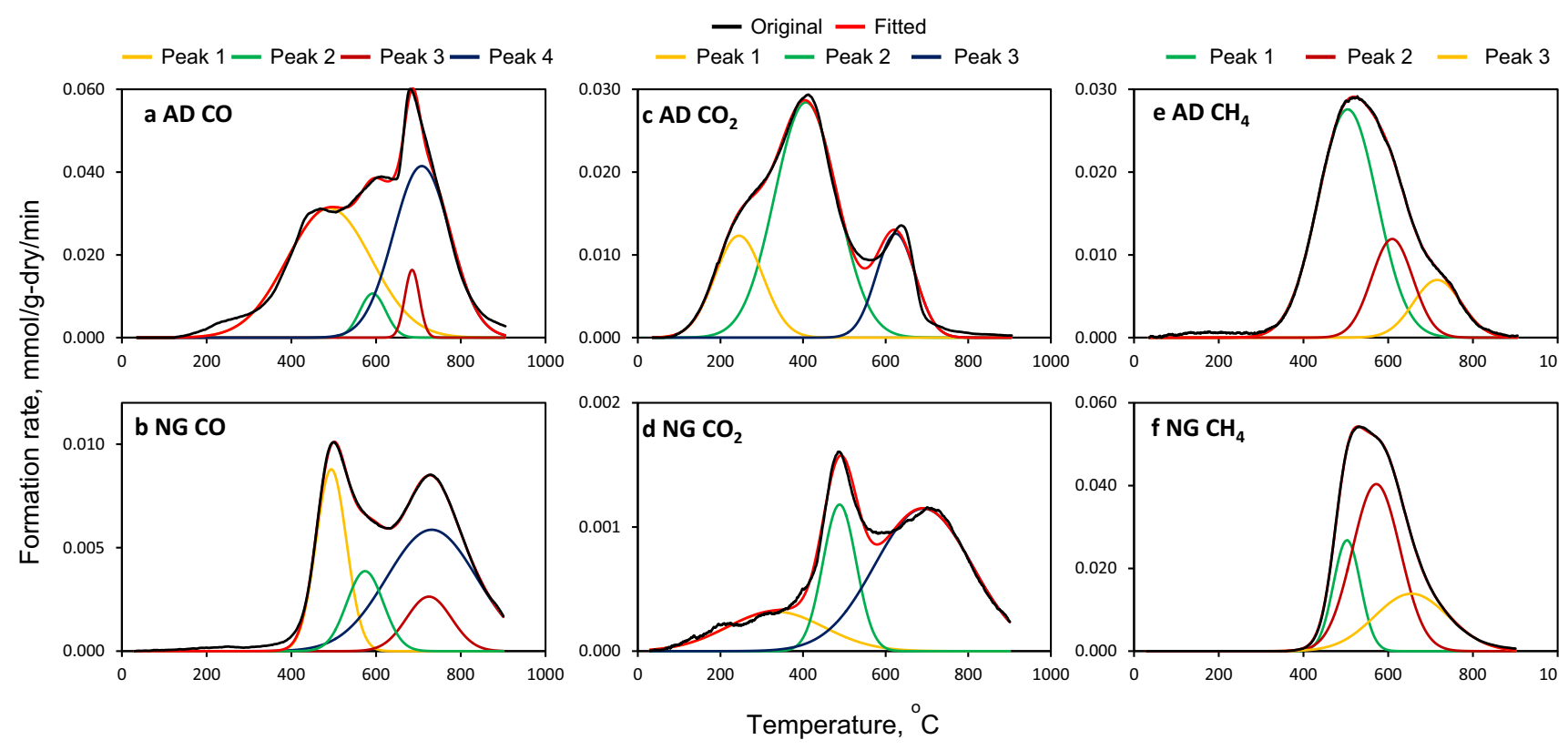

Fig. 6 Gas evolutions and deconvolutions as a function of the temperature for coal AD and NG

Table 4 Deconvolution results of coal AD and NG

\begin{tabular}{|c|c|c|c|c|}
\hline Item & Peak & Assignment & $\begin{array}{l}\text { Center } \\
\text { Temp. }\left({ }^{\circ} \mathrm{C}\right)\end{array}$ & $\begin{array}{l}\text { Gas amount } \\
(\mathrm{mmol})\end{array}$ \\
\hline \multirow[t]{4}{*}{ a $\mathrm{AD} \mathrm{CO}$} & Peak 1 & Methoxyl & 490 & 1.63 \\
\hline & Peak 2 & Anhydride & 592 & 0.17 \\
\hline & Peak 3 & Carbonyl & 685 & 0.15 \\
\hline & Peak 4 & Oxygen radical & 708 & 1.46 \\
\hline \multirow[t]{4}{*}{ b NG CO } & Peak 1 & Methoxyl & 494 & 0.17 \\
\hline & Peak 2 & Anhydride & 574 & 0.09 \\
\hline & Peak 3 & Carbonyl & 725 & 0.07 \\
\hline & Peak 4 & Oxygen radical & 731 & 0.33 \\
\hline \multirow[t]{3}{*}{ c $\mathrm{AD} \mathrm{CO} \mathrm{CO}_{2}$} & Peak 1 & Carboxyl & 245 & 0.36 \\
\hline & Peak 2 & Ester & 407 & 1.07 \\
\hline & Peak 3 & Anhydride & 625 & 0.29 \\
\hline \multirow[t]{3}{*}{$\mathrm{d} \mathrm{NG} \mathrm{CO} 2$} & Peak 1 & Carboxyl & 334 & 0.02 \\
\hline & Peak 2 & Ester & 489 & 0.02 \\
\hline & Peak 3 & Anhydride & 691 & 0.07 \\
\hline \multirow[t]{3}{*}{ e $\mathrm{AD} \mathrm{CH} \mathrm{CH}_{4}$} & Peak 1 & $\beta$-methyl & 504 & 1.00 \\
\hline & Peak 2 & Aryl methyl & 610 & 0.30 \\
\hline & Peak 3 & $\mathrm{C}_{2+}$-hydrocarbon & 716 & 0.20 \\
\hline \multirow[t]{3}{*}{ f $\mathrm{NG} \mathrm{CH}_{4}$} & Peak 1 & $\beta$-methyl & 503 & 0.45 \\
\hline & Peak 2 & Aryl methyl & 572 & 1.20 \\
\hline & Peak 3 & $\mathrm{C}_{2+}$-hydrocarbon & 655 & 0.63 \\
\hline
\end{tabular}

Hodek et al. 1991; Giroux et al. 2006). As shown in Fig. 6a, b and Table 4, we recognize that the $\mathrm{CO}$ formation is attributed to four independent reactions (correlation coefficients are higher than 99\%). CO formation at low temperatures was related with the cleavage of ether group (Reaction 2), and this reaction occurred at a relative wide temperature range from 300 to $500{ }^{\circ} \mathrm{C}$ (Liu et al. 2014a, b). Peak 1 is thus assigned to Reaction 2 . The reaction indicated by Peak 2 should be caused by the pyrolysis of anhydrides, which forms $\mathrm{CO}$ and $\mathrm{CO}_{2}$ at ca. $600{ }^{\circ} \mathrm{C}$ (Otake and Jenkins 1993; Zhuang et al. 1994a, b). Note that parts of these anhydrides existed originally in the raw coals, while other parts should come from the condensation of $\mathrm{COOH}$ groups simultaneous with the $\mathrm{H}_{2} \mathrm{O}$ formation. Peak 3 was relative with the cleavage of carbonyls, which can produce CO at a high temperature (Figueiredo et al. 1999). Peak 4 can be assigned to free radical reactions. As above mentioned, the quantity of $\mathrm{Ar}-\mathrm{O}$ started decreasing greatly since $500{ }^{\circ} \mathrm{C}$, meanwhile the further condensation among aromatic rings were initiated. The condensation processes removed the $\mathrm{O}$ atoms, which then reacted with $\mathrm{C}$ and $\mathrm{H}$ atoms easily to form $\mathrm{CO}$ and $\mathrm{H}_{2} \mathrm{O}$, respectively.

The reactions involving oxygen free radicals were the main sources of $\mathrm{CO}$ formation both for $\mathrm{AD}$ and for $\mathrm{NG}$, while one of the $\mathrm{CO}$ sources of NG at low temperature, the cleavage of ether groups, was not as significant as that of AD. This means the ether groups should widespread in subbituminous coal.

\subsection{Mechanism of $\mathrm{CO}_{2}$ formation}

The deconvolution results of rate profiles of $\mathrm{CO}_{2}$ formation are shown in Fig. $6 c$ and d, in which Peak 1 is located at 


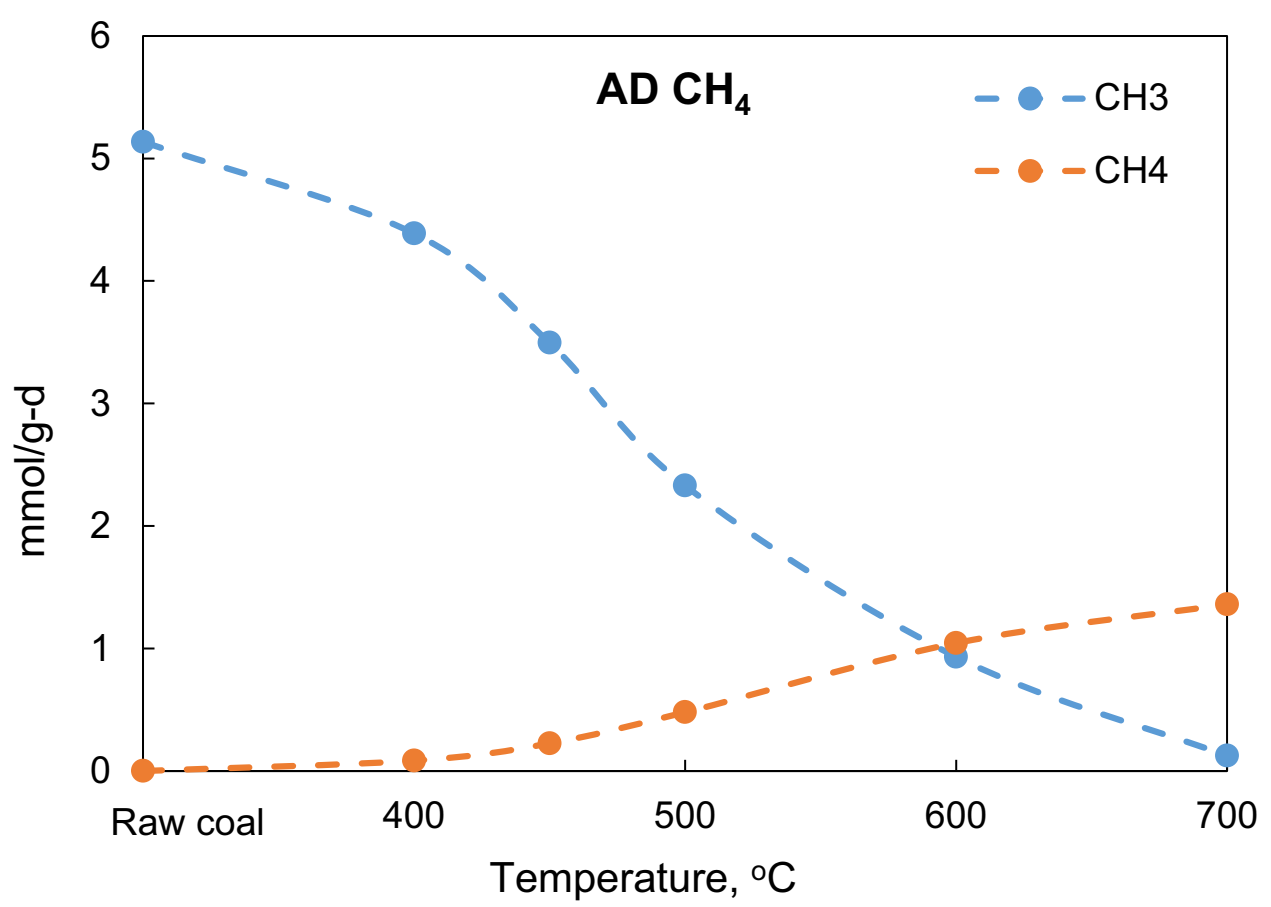

Fig. 7 Integration of $\mathrm{CH}_{4}$ as a function of temperature and the trends of its relevant functional groups of $-\mathrm{CH}_{3}$ of coal $\mathrm{AD}$

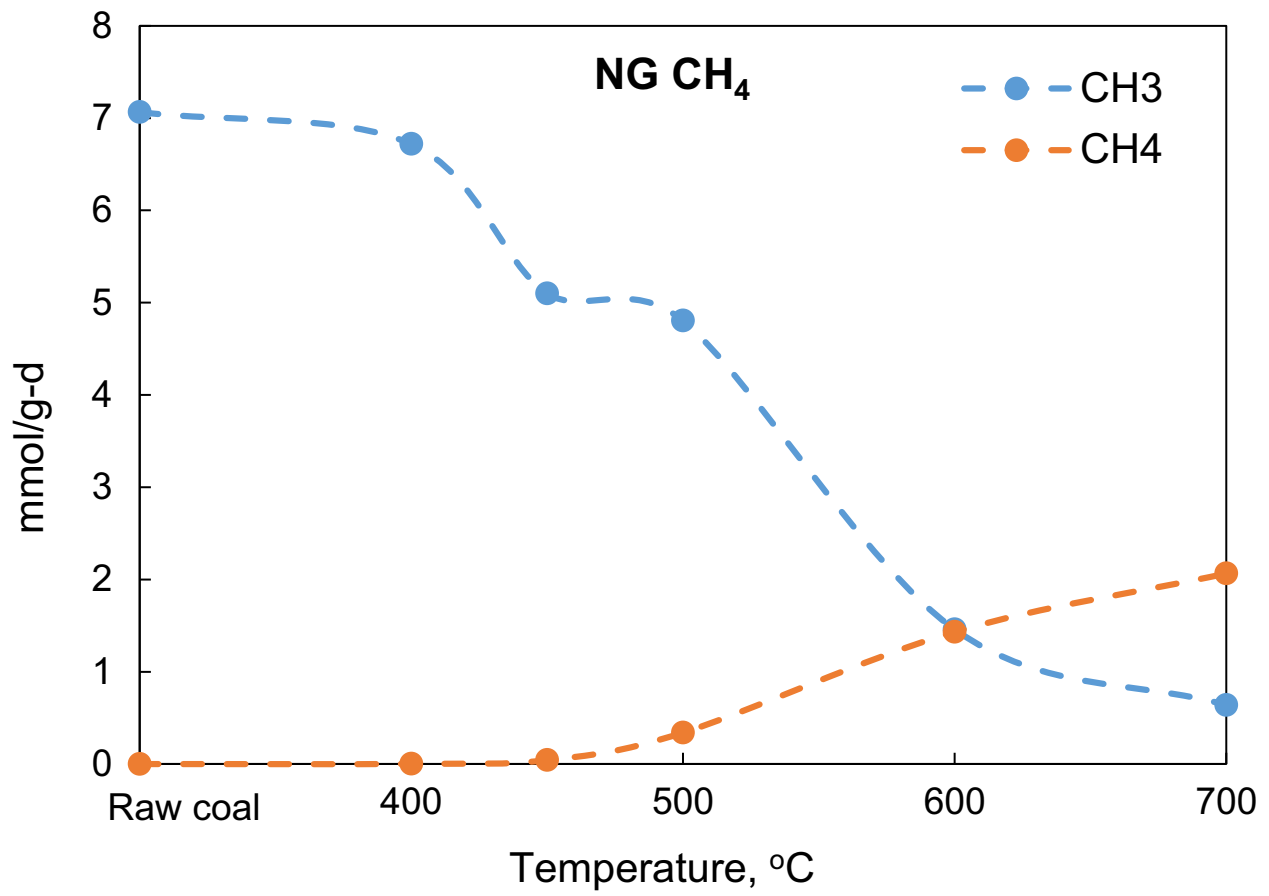

Fig. 8 Integration of $\mathrm{CH}_{4}$ as a function of temperature and the trends of its relevant functional groups of $-\mathrm{CH}_{3}$ of $c 0 a l \mathrm{NG}$

low temperature, and Peak 2 and 3 are located at 400 and $600{ }^{\circ} \mathrm{C}$. These three peaks were attributed to the removal of carboxyl, ester group, and anhydride, respectively (Vinke et al. 1994; Zhuang et al. 1994a, b; Zielke et al. 1996; Zhao 2007). Note that, according to previous studies, the Peak 3 might include a few contributions from the decomposition of mineral substances at the temperature range from 600 to $700{ }^{\circ} \mathrm{C}$ ( $\mathrm{Li} \mathrm{2009}$; Wang et al. 2012), otherwise the quantity of $\mathrm{CO}_{2}$ formed at this temperature range should be same with that of $\mathrm{CO}$ (see Peak 2 of Table $4 a, b)$ since the decomposition of anhydrides could generate same amount of $\mathrm{CO}_{2}$ and $\mathrm{CO}$. 


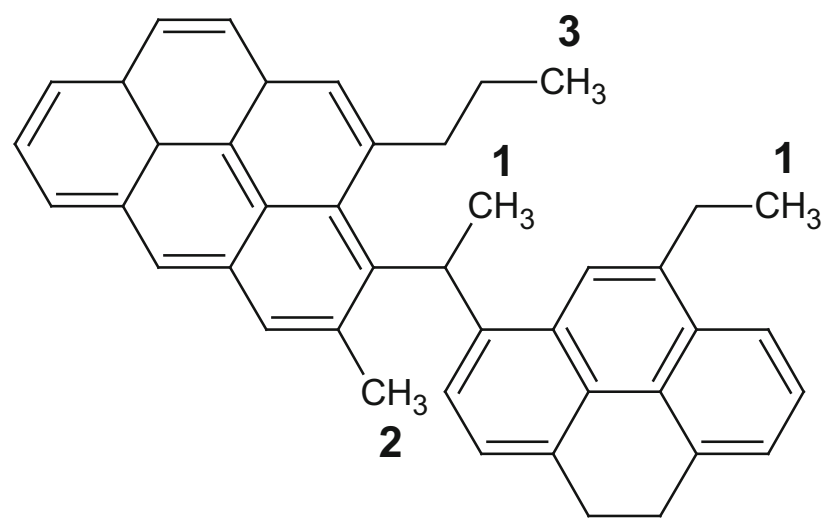

Fig. 9 Segmental structure of coal for illustrating different kinds of methyl groups

In Table 4, the quantities of $\mathrm{CO}_{2}$ of $\mathrm{AD}$ and $\mathrm{NG}$ are so different that $\mathrm{CO}_{2}$ formation of $\mathrm{AD}(1.72 \mathrm{mmol})$ is 15 times as much as that of $\mathrm{NG}(0.11 \mathrm{mmol})$. This was mainly caused by the different quantities of $\mathrm{COO}$ and $\mathrm{C}=\mathrm{O}$ groups in $\mathrm{AD}$ and NG. There was $1.8 \mathrm{mmol} \mathrm{COO}$ and $\mathrm{C}=\mathrm{O}$ in $\mathrm{AD}$, while that in NG was only $0.6 \mathrm{mmol}$.

\subsection{Mechanism of $\mathrm{CH}_{4}$ formation}

The formation of $\mathrm{CH}_{4}$ was related with the cleavage of $\mathrm{CH}_{3}$. As shown in Figs. 7 and 8, with increasing the temperature, the quantity of $-\mathrm{CH}_{3}$ decreases gradually, and the $\mathrm{CH}_{4}$ is produced continuously. There were several $-\mathrm{CH}_{3}$ types in coal, and the removals of different $-\mathrm{CH}_{3}$ groups occurred at different temperature ranges. The $-\mathrm{CH}_{3}$ attached to the aromatic rings in coal molecules can be classified into three groups in addition to those bonding with heteroatoms (Fig. 9). However, these $-\mathrm{CH}_{3}$ types cannot be distinguished from each other through ${ }^{13} \mathrm{C}$ NMR spectra.

As shown in Fig. 6e, $\mathrm{f}$, the formation of $\mathrm{CH}_{4}$ can be attributed to three independent reactions. At the temperature range from 400 to $700{ }^{\circ} \mathrm{C}$, the $\mathrm{CH}_{4}$ should be generated from the cleavage of $\beta-\mathrm{CH}_{3}\left(-{ }^{1} \mathrm{CH}_{3}\right.$ in Fig. 9). When the temperature was elevated to $600{ }^{\circ} \mathrm{C}$, the cleavage of Ar- $\mathrm{CH}_{3}$ occurred $\left(-{ }^{2} \mathrm{CH}_{3}\right.$ in Fig. 9). The formation of $\mathrm{CH}_{4}$ at the temperature higher than $600{ }^{\circ} \mathrm{C}$ should be related with the secondary pyrolysis of the long-chain alkanes attached to aromatic rings, since the pyrolysis of such alkanes required very high energy $\left(-{ }^{3} \mathrm{CH}_{3}\right.$ in Fig. 9). Our study is also supported by previous reports (Zhao 2007; Li 2009; Porada 2004). Liu et al. (2014a, b) proposed the mechanisms of $\mathrm{CH}_{4}$ formation for coal pyrolysis at the temperature range from 400 to $700{ }^{\circ} \mathrm{C}$, which is well consistent with our results.

In Fig. 6e, $\mathrm{f}$, the temperature range of $\mathrm{CH}_{4}$ formation of $\mathrm{AD}$ is similar with that of $\mathrm{NG}$. However, compared with $\mathrm{AD}$, whose $\beta-\mathrm{CH}_{3}$ is the main resource for $\mathrm{CH}_{4}$ formation, the $\mathrm{CH}_{4}$ produced by $\mathrm{NG}$ is mainly generated from the cleavage of $\mathrm{Ar}-\mathrm{CH}_{3}$. This means that there are many bridged alkyls and long side chains in the coal molecules of

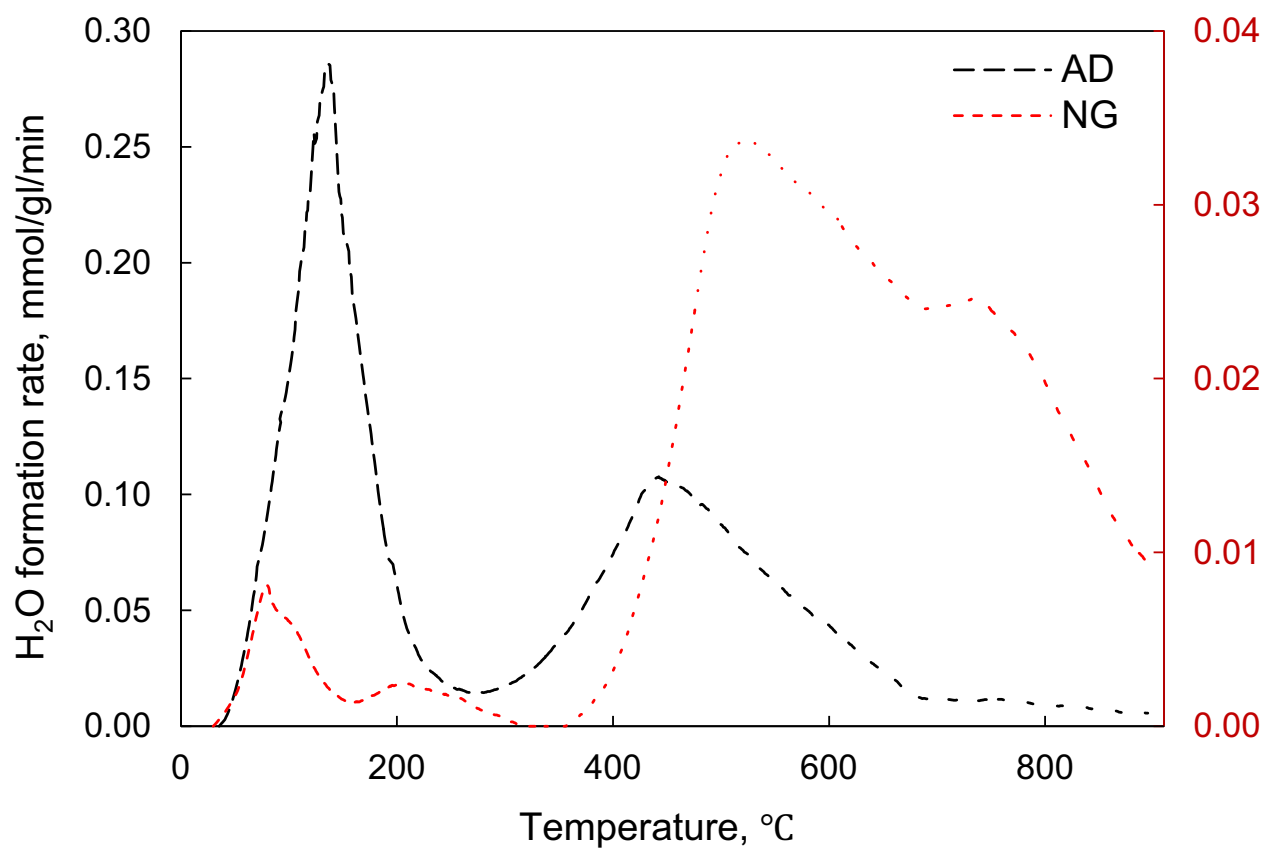

Fig. $10 \mathrm{H}_{2} \mathrm{O}$ evolution rates as a function of temperature for coal AD and NG 
$\mathrm{AD}$, while the condensed degree of NG is much higher than that of $\mathrm{AD}$, such that the alkyls of NG are mainly attached to the aromatic rings.

\subsection{Mechanism of $\mathrm{H}_{2} \mathrm{O}$ formation}

As shown in Fig. 10, the temperature range from ambient to $900{ }^{\circ} \mathrm{C}$ for $\mathrm{H}_{2} \mathrm{O}$ formation is wider than that of any other gases. The physically adsorbed $\mathrm{H}_{2} \mathrm{O}$ in coal was emitted when the temperature is lower than $300{ }^{\circ} \mathrm{C}$, while the pyrolysis of coal (mainly as the cleavage of - $\mathrm{OH}$ groups) at the temperature higher than $300{ }^{\circ} \mathrm{C}$ became the main resource of $\mathrm{H}_{2} \mathrm{O}$ formation (Suuberg et al. 1985; Ibarra et al. 1991). The formation of $\mathrm{H}_{2} \mathrm{O}$ was closely related with so many potential reactions that its temperature range is the widest. It was thus impossible to deconvolve its formation profile exactly. For example, as seen in Reactions 9-11, the cleavage of - $\mathrm{OH}$ was an important source for $\mathrm{H}_{2} \mathrm{O}$ formation, while other groups such as ether, ester, and anhydride that underwent pyrolysis at high temperature would produce oxygen free radicals to generate $\mathrm{H}_{2} \mathrm{O}$ eventually as well. secondary effects of some reactions such as cyclization of side chains containing hydroxyl groups and condensation of O-containing aromatics. The quantity of Al-O increases temporarily as well, because of the migration of $\mathrm{O}$ free radicals.

(3) The formation of $\mathrm{H}_{2} \mathrm{O}$ must be followed by those of $\mathrm{CO}$ and $\mathrm{CO}_{2}$. With the formation of anhydrides, esters, and ethers, the reactions among different carboxyl and hydroxyl groups during coal pyrolysis generate $\mathrm{H}_{2} \mathrm{O}$ first, and then their further reactions of removing anhydrides and esters must cause the formations of $\mathrm{CO}$ and $\mathrm{CO}_{2}$.

(4) The formation of $\mathrm{CH}_{4}$ is relatively independent from that of other volatile products. It is generated by the cleavages of $\beta-\mathrm{CH}_{3}, \mathrm{Ar}-\mathrm{CH}_{3}$, and long chain alkanes attached to the aromatic rings in coal molecules. The dissociation energies of methyls of different locations are greatly different from each other, so the main temperature ranges for $\mathrm{CH}_{4}$ formation depend largely on the coal ranks.

(coal)Ar-

$($ coal) $\mathrm{Ar}-($ o

$($ coal $) \mathrm{Ar}-($ coal $) \mathrm{Ar} \rightarrow$

\section{Conclusions}

Based on the QMS analysis of the product gases of NG and $\mathrm{AD}$ and the ${ }^{13} \mathrm{C}$ NMR spectra, the mechanism of coal structure changes at molecular level during pyrolysis are quantitatively revealed.

(1) The CO formation can be mainly attributed to the cleavage of ether group, the removal of anhydrides, oxygen free radicals reaction, and cleavage of carbonyl groups. The removals of carboxyl, ester, and anhydride groups are the main reasons for the $\mathrm{CO}_{2}$ formation.

(2) The quantity of Ar-O during coal pyrolysis will temporarily increase during coal pyrolysis due to the
In addition, the different performances of coals with different ranks during pyrolysis are ascribed to their different quantities and distributions of O-containing functional groups, alkyls, and scales of aromatic rings. Representing caking coals, NG has less substituents, but higher aromaticity and condensation degree than those of AD representing sub-bituminous coals.

Acknowledgements The authors are also grateful to the China Scholarship Council (Grant Numbers 201406420035 and 201406420041).

Open Access This article is distributed under the terms of the Creative Commons Attribution 4.0 International License (http://creative commons.org/licenses/by/4.0/), which permits unrestricted use, 
distribution, and reproduction in any medium, provided you give appropriate credit to the original author(s) and the source, provide a link to the Creative Commons license, and indicate if changes were made.

\section{References}

Arenillas A, Rubiera F, Pis JJ (1999) Simultaneous thermogravimetric-mass spectrometric study on the pyrolysis behavior of different rank coals. J Anal Appl Pyrolysis 50:31-46

Attar A, Hendrickson GG (1980) Pyrolysis of the polymer coal: structure and kinetics. Am Chem Soc Div Fuel Chem Prepr. US 25 ISBN CONF-800814-P3

Axelson DE (1985) Solid state nuclear magnetic resonance of fossil fuels. Brookfield Publishing Co. Inc, Brookfield. ISBN 0-919868-25-8

Davidson RM (1986) Nuclear magnetic resonance studies of coal. IEA Coal Research, Or IEA Coal Research, London, London

Dollimore D, Gamlen GA, Taylor TJ (1984) Mass spectrometric evolved gas analysis-an overview. Thermochim Acta 75:5969

Duan CL (2007) Structural characteristics of low-middle rank coals and generation mechanisms of methane and hydrogen during pyrolysis. Master dissertation of Taiyuan University of Technology

Duan LB, Zhao CS, Zhou W, Qu CR, Chen XP (2009) Investigation on coal pyrolysis in $\mathrm{CO}_{2}$ atmosphere. Energy Fuels 23:3826-3830

Figueiredo JL, Pereira MFR, Freitas MMA, Orfao JJM (1999) Modification of the surface chemistry of activated carbons. Carbon 37:1379-1389

Fletcher TH, Kerstein AR (1990) Chemical percolation model for devolatilization. 2. Temperature and heating rate effects on product yields. Energy Fuels 4:54-60

Fletcher TH, Kerstein AR (1992) Chemical percolation model for devolatilization. 3. Direct use of $13 \mathrm{C}$ NMR data to predict effects of coal type. Energy Fuels 6:414-431

Genetti D, Fletcher TH, Pugmire RJ (1999) Development and application of a correlation of 13C NMR chemical structural analyses of coal based on elemental composition and volatile matter content. Energy Fuels 13:60-68

Giroux L, Charland JP, MacPhee JA (2006) Application of thermogravimetric fourier transform infrared spectroscopy (TG-FTIR) to the analysis of oxygen functional groups in coal. Energy Fuels 20:1988-1996

Grant DM, Pugmire RJ (1989) Chemical model of coal devolatilization using percolation lattice statistics. Energy Fuels 3:175-186

Hodek W, Kirschstein J, Heek KHV (1991) Reactions of oxygen containing structures in coal pyrolysis. Fuel 70(3):424-428

Ibarra JV, Moliner R, Gavilan MP (1991) Functional group dependence of cross-linking reactions during pyrolysis of coal. Fuel 70(3):408-413

Jia LY, Weng JJ, Wang Y, Sun SB, Zhou ZY, Qi F (2013) Online analysis of volatile products from bituminous coal pyrolysis with synchrotron vacuum ultraviolet photoionization mass spectrometry. Energy Fuels 27:694-701

Kazuhiro M, Taisuke M, Kouichi M (2002) A new method for estimating the cross-linking reaction during the pyrolysis of brown coal. J Chem Eng Jpn 35(8):778-785

Kidena K, Murata S, Artok L, Nomura M (1999) Estimation of the average aromatic cluster size based on solid-state NMR measurement of coal. Jpn Inst Energy 78:869-876
Le CD, Kolaczkowski ST, McClymont DEJ (2015) Using quadrupole mass spectrometry for on-line gas analysis-Gasification of biomass and refuse derived fuel. Fuel 139:337-345

Li MF (2009) Experimental study on kinetics and mechanisms of the main gaseous products generation from low rank coal pyrolysis. Doctoral dissertation of Taiyuan University of Technology

Liu SY, Zhang ZQ, Wang HF (2012) Quantum chemical investigation of the thermal pyrolysis reactions of the carboxylic group in a brown coal model. J Mol Model 18:359-365

Liu JX, Jiang XM, Shen J, Zhang H (2014a) Pyrolysis of superfine pulverized coal. Part 1. Mechanisms of methane formation. Energy Convers Manag 87:1027-1038

Liu JX, Jiang XM, Shen J, Zhang H (2014b) Pyrolysis of superfine pulverized coal. Part 2. Mechanisms of carbon monoxide formation. Energy Convers Manag 87:1039-1049

Miknis FP (1996) Applications of solid-state NMR in oil shale research. Ann Rep NMR Spectros 33:207-246

Mori A, Kubo S, Kudo S, Norinaga K, Kanai T, Aoki H, Hayashi JI (2011) Preparation of high-strength coke by carbonization of hot-briquetted Victorian brown coal. Energy Fuels 26:296-301

Ndaji FE, Butterfield LM, Thomas KM (1997) Changes in the macromolecular structure of coals with pyrolysis temperature. Fuel 76(2):169-177

Niksa S (1991a) FLASHCHAIN theory for rapid coal devolatilization kinetics. 1. Formulation. Energy Fuels 5:647-665

Niksa S (1991b) FLASHCHAIN theory for rapid coal devolatilization kinetics. 2. Impact of operating conditions. Energy Fuels 5:665-673

Niksa S (1991c) FLASHCHAIN theory for rapid coal devolatilization kinetics. 3. Modeling the behavior of various coals. Energy Fuels 5:673-683

Niksa S (1995) Predicting the devolatilization behavior of any coal from its ultimate analysis. Combust Flame 100:384-394

Otake Y, Jenkins RG (1993) Characterization of oxygen-containing surface complexes created on a microporous carbon by air and nitric acid treatment. Carbon 31(1):109-121

Perry ST, Hambly EM, Fletcher TH, Solum MS, Pugmire RJ (2000) Solid-state 13C NMR characterization of matched tars and chars from rapid coal devolatilization. Proc Combust Inst 28:2313-2319

Porada S (2004) The reactions of formation of selected gas products during coal pyrolysis. Fuel 83:1191-1196

Poutsma ML (1990) Free-adical thermolysis and hydrogenolysis of model hydrocarbons relevant to processing of coal. Energy Fuels 4(2):113-131

Seebauer V, Petek J, Staudinger G (1997) Effects of particle size, heating rate and pressure on measurement of pyrolysis kinetics by thermogravimetric analysis. Fuel 76(13):1277-1282

Shabbar S, Janajreh I (2013) Thermodynamic equilibrium analysis of coal gasification using Gibbs energy minimization method. Energy Convers Manag 65:755-763

Solomon PR (1994) Impact of coal pyrolysis on combustion. In: Symposium (International) on Combustion pp 463-474

Solomon PR, Hamblen DG, Carangelo RM, Serio MA, Deshpande GV (1988) General model of coal devolatilization. Energy Fuels 2:405-422

Solomon PR, Hamblen DG, Yu ZZ, Serio MA (1990a) Network models of coal thermal decomposition. Fuel 69(7):754-763

Solomon PR, Serio MA, Carangelo RM, Bassilakis R (1990b) Analysis of the argonne premium coal samples by thermogravimetric fourier transform infrared spectroscopy. Energy Fuels 4:319-333

Solomon PR, Serio MA, Despande GV, Kroo E (1990c) CrossLinking reactions during coal conversion. Energy Fuels 4:42-54

Solomon PR, Serio MA, Suuberg EM (1992) Coal pyrolysis: experiments, kinetic rates and mechanisms. Prog Energy Combust Sci 18:133-220 
Solomon PR, Hamblen DG, Serio MA, Yu ZZ, Charpenay S (1993) A characterization method and model for predicting coal conversion behavior. Fuel 72(4):469-488

Solum MS, Pugmire RJ, Grant DM (1989) 13C Solid-state NMR of argonne premium coals. Energy Fuels 3:187-193

Sun QL, Li W, Chen HK, Li BQ (2003) The variation of structural characteristics of macerals during pyrolysis. Fuel 82:669-676

Suuberg EM, Lee D, Larsen JW (1985) Temperature dependence of crosslinking processes in pyrolysing coals. Fuel 64(12):1668-1671

Tian YJ, Xie KC, Zhu SY, Fletcher TH (2001) Simulation of coal pyrolysis in plasma jet by CPD model. Energy Fuels 15:1354-1358

Vinke P, Eijk MVD, Verbree M, Voskamp AF, Bekkum HV (1994) Modification of the surfaces of a gas-activated carbon and a chemically activated carbon with nitric acid, hypochlorite, and ammonia. Carbon 32(4):675-686

Wang M, Dong Q, Lu SF, Tian SS, Chen GH, Sun YF (2012) Pyrolysis products characteristics and kinetic analysis of coal from Shahezi Formation of Songliao Basin under the TG-MS experiment. J Chin Coal Soc 37(7):1150-1155

Wang PF, Jin LJ, Liu JH, Zhu SW, Hu HQ (2013a) Analysis of coal tar derived from pyrolysis at different atmospheres. Fuel 104:14-21
Wang SQ, Tang YG, Schobert HH, Guo YN, Gao WC, Lu XK (2013b) FTIR and simultaneous TG/MS/FTIR study of late permian coals from Southern China. J Anal Appl Pyrolysis 100:75-80

Wu D, Liu GJ, Sun RY (2014) Investigation on structural and thermodynamic characteristics of perhydrous bituminous coal by fourier transform infrared spectroscopy and thermogravimetry/mass spectrometry. Energy Fuels 28:3024-3035

Zhao LH (2007) Research of reactivities of coal during pyrolysis and gasification. Master dissertation of Taiyuan University of Technology

Zhuang QL, Kyotani T, Tomita A (1994a) DRIFT and TK/TPD analyses of surface oxygen complexes formed during carbon gasification. Energy Fuels 8:714-718

Zhuang QL, Kyotani T, Tomita A (1994b) The change of TPD pattern of $\mathrm{O}_{2}$-gasified carbon upon air exposure. Carbon 32(3):539-540

Zielke U, Huttinger KJ, Hoffman WP (1996) Surface-oxidized carbon fibers: I. Surface structure and chemistry. Carbon 34(8):983-998 